OPEN ACCESS

Edited by:

Nils Erik Gilhus,

University of Bergen, Norway

Reviewed by:

Yuwei Da,

Capital Medical University, China

Saiju Jacob,

University Hospitals Birmingham NHS

Foundation Trust, United Kingdom

Leslie Jacobson,

University of Oxford, United Kingdom

*Correspondence:

Socrates J. Tzartos

stzartos@gmail.com

Konstantinos Lazaridis klazaridis@pasteur.gr

Specialty section:

This article was submitted to Neuromuscular Diseases,

a section of the journal

Frontiers in Neurology

Received: 20 August 2020

Accepted: 30 October 2020 Published: 30 November 2020

Citation:

Lazaridis K and Tzartos SJ (2020) Myasthenia Gravis: Autoantibody Specificities and Their Role in MG Management

Front. Neurol. 11:596981. doi: 10.3389/fneur.2020.596981

\section{Myasthenia Gravis: Autoantibody Specificities and Their Role in MG Management}

\author{
Konstantinos Lazaridis ${ }^{1 *}$ and Socrates J. Tzartos ${ }^{2,3 *}$ \\ ${ }^{1}$ Department of Immunology, Hellenic Pasteur Institute, Athens, Greece, ${ }^{2}$ Tzartos NeuroDiagnostics, Athens, Greece, \\ ${ }^{3}$ Department of Neurobiology, Hellenic Pasteur Institute, Athens, Greece
}

Myasthenia gravis (MG) is the most common autoimmune disorder affecting the neuromuscular junction, characterized by skeletal muscle weakness and fatigability. It is caused by autoantibodies targeting proteins of the neuromuscular junction; 85\% of MG patients have autoantibodies against the muscle acetylcholine receptor (AChR$M G$ ), whereas about $5 \%$ of MG patients have autoantibodies against the muscle specific kinase (MuSK-MG). In the remaining about $10 \%$ of patients no autoantibodies can be found with the classical diagnostics for AChR and MuSK antibodies (seronegative MG, SN-MG). Since serological tests are relatively easy and non-invasive for disease diagnosis, the improvement of methods for the detection of known autoantibodies or the discovery of novel autoantibody specificities to diminish SN-MG and to facilitate differential diagnosis of similar diseases, is crucial. Radioimmunoprecipitation assays (RIPA) are the staple for MG antibody detection, but over the past years, using cellbased assays (CBAs) or improved highly sensitive RIPAs, it has been possible to detect autoantibodies in previously SN-MG patients. This led to the identification of more patients with antibodies to the classical antigens AChR and MuSK and to the third MG autoantigen, the low-density lipoprotein receptor-related protein 4 (LRP4), while antibodies against other extracellular or intracellular targets, such as agrin, $\mathrm{K}_{\mathrm{v}} 1.4$ potassium channels, collagen $\mathrm{Q}$, titin, the ryanodine receptor and cortactin have been found in some MG patients. Since the autoantigen targeted determines in part the clinical manifestations, prognosis and response to treatment, serological tests are not only indispensable for initial diagnosis, but also for monitoring treatment efficacy. Importantly, knowing the autoantibody profile of MG patients could allow for more efficient personalized therapeutic approaches. Significant progress has been made over the past years toward the development of antigen-specific therapies, targeting only the specific immune cells or autoantibodies involved in the autoimmune response. In this review, we will present the progress made toward the development of novel sensitive autoantibody detection assays, the identification of new MG autoantigens, and the implications for improved antigen-specific therapeutics. These advancements increase our understanding of MG pathology and improve patient quality of life by providing faster, more accurate diagnosis and better disease management.

Keywords: autoimmunity, myasthenia gravis, autoantibody, diagnosis, therapy, acetylcholine receptor, MuSK, LRP4 


\section{INTRODUCTION}

Myasthenia gravis (MG) is an antibody-mediated autoimmune disorder affecting skeletal muscles, characterized by fluctuating muscle weakness and abnormal fatigability. MG is caused by autoantibodies, which target proteins of the neuromuscular junction (NMJ), damaging the postsynaptic muscle membrane and impairing signal transmission from motor neurons to the muscle $(1,2)$.

The organization of the NMJ is crucial for effective signal transmission $(3,4)$. Acetylcholine receptors (AChRs) on the muscle cell membrane bind acetylcholine released from the axon terminals and open to allow inflow of ions, which leads to depolarization of the membrane. The AChRs are clustered at the NMJ resulting in a localized high density of receptors, which ensures the efficiency of signal transmission. Neural agrin, released from nerve terminals, binds to low-density lipoprotein receptor-related protein 4 (LRP4) on the muscle membrane, activating it to form complexes with muscle specific kinase (MuSK). This results in the phosphorylation and activation of MuSK, which in turn leads to rapsyn-mediated AChR clustering at the NMJ (Figure 1).

MG is heterogeneous in terms of symptom presentation, as well as pathophysiology, since different proteins of the NMJ can be targeted $(6,7)$. MG symptoms usually manifest initially at the ocular muscles and in $\sim 15 \%$ of patients they remain localized, commonly referred to as ocular MG (OMG). In the majority of patients, however, the symptoms progress within a couple of years to other skeletal muscles leading to generalized MG (GMG). In terms of age of onset the disease presents with two peaks of incidence: the first well below the age of 50, termed early-onset MG (EOMG), more commonly affecting women and the second above the age of 50 (late-onset MG, LOMG) more common among men.

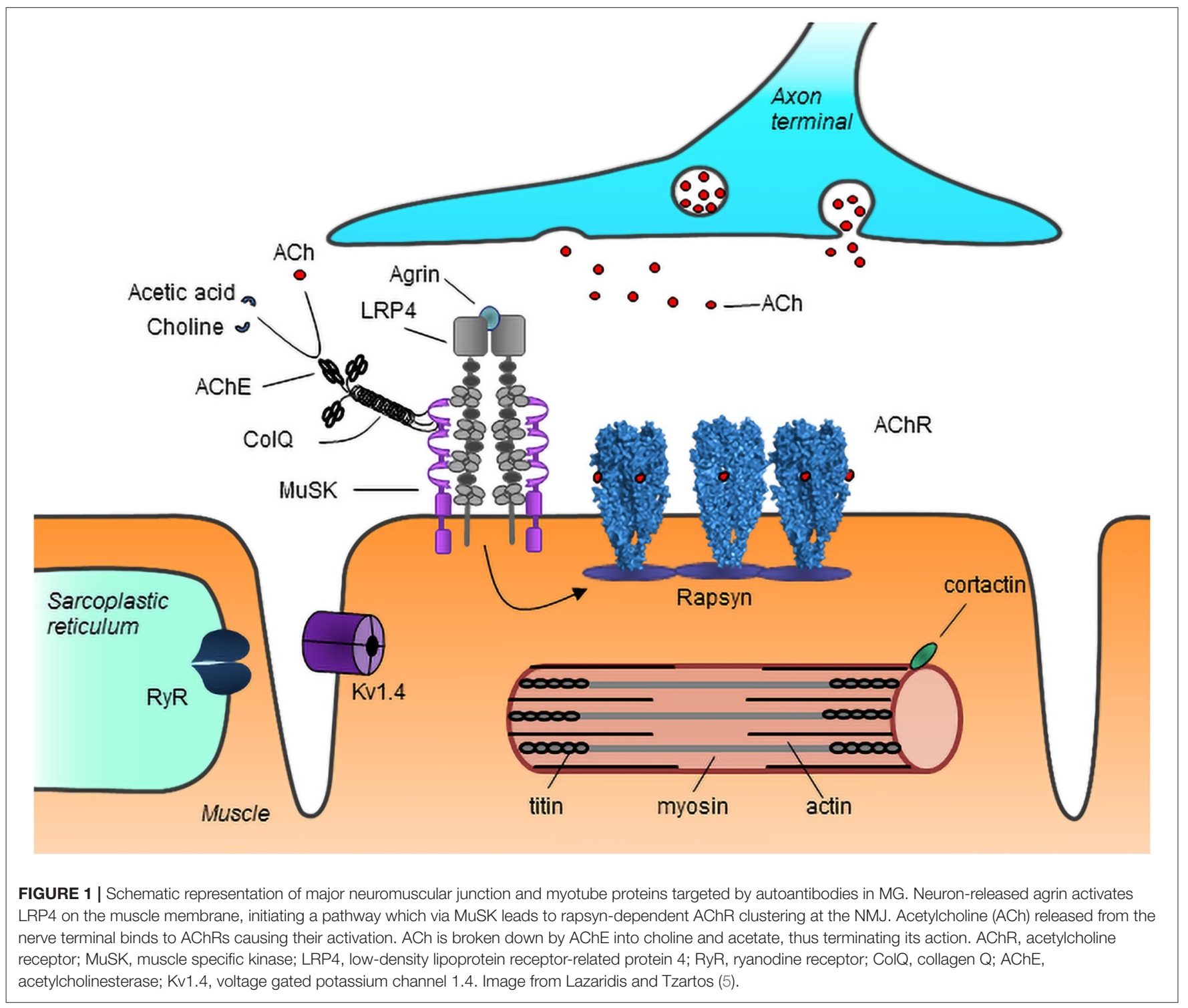


Although $\mathrm{MG}$ is a relatively rare disease with a prevalence of 150-300 per million population and an incidence of $\sim 10$ per million per year (8), it is considered a model antibody-mediated autoimmune disorder, due to the extensive characterization of the main autoantibodies and target antigens. In more detail, in most patients $(\sim 85 \%)$ the autoantibodies target the muscle AChR. In $\sim 6 \%$ of patients the autoantibodies target MuSK, while autoantibodies targeting LRP4 are found in about $2 \%$ of MG patients. The pathogenicity of autoantibodies has been demonstrated by the improvement of patients' symptoms following plasmapheresis and by the onset of passive transfer experimental autoimmune MG (EAMG) when they are injected into experimental animals (9-13). Patients without detectable autoantibodies are referred to as seronegative (SNMG). Some MG patients have antibodies against a number of other extracellular or intracellular targets. Although the pathogenicity of these autoantibodies is often uncertain or unlikely, they can still be very valuable as disease biomarkers.

The detection of autoantibodies is crucial for MG diagnosis and for the differential diagnosis of many disorders with similar presentation. We will review the main autoantibodies found in MG, their implications for diagnosis and patient stratification, and recent advances for improved diagnostics based on more sensitive tests or the discovery of new target antigens. In addition, we will present an overview of recent efforts to develop targeted therapeutic methods aiming only at the antigen-specific components of the immune system, further highlighting the importance of autoantigen determination in MG diagnosis.

\section{MG CLASSIFICATION BASED ON AUTOANTIBODY SPECIFICITY}

\section{Patients With AChR Antibodies}

AChRs are located at the end plate of the muscle post-synaptic membrane, opposite the axon terminals. They are composed of five homologous subunits with a stoichiometry of $\alpha_{2} \beta \delta \varepsilon$ in adult and $\alpha_{2} \beta \gamma \delta$ in fetal or adult denervated muscles (14). The autoantibodies target the $\mathrm{N}$-terminal extracellular domains (ECDs) of the AChR subunits. About half of the autoantibodies bind the AChR $\alpha$ subunit and studies in experimental rats have suggested that these are the most pathogenic (10). A region of the $\alpha$ subunit composed mainly by amino acids $67-76$ with some contribution from other segments has been identified to be particularly targeted, commonly referred to as the main immunogenic region (MIR) (15-17). However, autoantibodies against all five subunits, including the $\gamma$ subunit of the fetal $\mathrm{AChR}$, can be found, even in the same patient (18-21).

AChR antibodies confer their pathogenicity by three mechanisms. Firstly, they can activate the complement cascade, since they belong mainly to the IgG1 and IgG3 subclasses, thus causing destruction of the post-synaptic membrane $(22,23)$. The loss of the typical local architecture results in a severely diminished efficiency of signal transduction between nerve and muscle. Secondly, they can cross-link AChRs causing their internalization and destruction by a process called antigenic modulation, thus leading to a reduction in the number of functional receptors in the post-synaptic membrane (24). Lastly, antibodies that bind close to the AChR ligand binding site are thought to directly block acetylcholine binding and receptor activation (25).

The detection of serum AChR antibodies has been an invaluable tool in the diagnosis of MG. Although the AChR antibody titer does not correlate with disease severity across different MG patients, the temporal variation of titers from individual patients appear to be associated not only with symptom severity but with response to treatment as well (26). Therefore, in addition to diagnosis, AChR antibody measurement can be useful for MG patient monitoring. Nonetheless, in very rare cases AChR antibodies can be found in non-MG patients with other autoimmune disorders or with thymoma (27).

\section{Patients With MuSK Antibodies}

MuSK is a key player involved in NMJ organization and maintenance. It is located on the muscle membrane where it interacts with LRP4 propagating the signal for AChR clustering, while it is involved in tethering acetylcholisteresase (AChE) via interactions with collagen $\mathrm{Q}$ (ColQ). MuSK is a transmembrane protein with an extracellular domain containing three immunoglobulin-like regions and a frizzled-like region, a transmembrane helix domain and a cytoplasmic domain with tyrosine kinase activity. Most of the MuSK antibodies are directed against the immunoglobulin-like regions of the extracellular domain $(28,29)$. This binding appears to block the interactions of MuSK with LRP4 or ColQ resulting in reduction of both agrin-dependent and agrin-independent AChR clustering (3032). Antigenic modulation and complement activation are not thought to be significant in pathology, since MuSK antibodies are mostly of the IgG4 subclass, which does not activate complement and is functionally monovalent $(33,34)$. Nonetheless, since IgG1$-3 \mathrm{MuSK}$ antibodies are also present in patients' sera, they could have pathogenic activity, although their relative contribution remains unclear.

MuSK antibodies are found in about 6\% of MG patients, accounting for $40 \%$ of patients without AChR antibodies. However, their prevalence varies among countries possibly due to genetic and environmental factors, with northern European countries presenting lower rates than those in south Europe and the Mediterranean $(29,35-39)$, while in Japanese populations they are even less common with a prevalence of $2-3 \%$ (40). Similarly to AChR antibodies, their detection is crucial for MG diagnosis and monitoring. Interestingly, their titer has been shown to positively correlate with symptom severity not only in individual patients but in the population as well $(41,42)$.

\section{Patients With LRP4 Antibodies}

LRP4 is a transmembrane protein, containing several low-density lipoprotein domains, expressed in skeletal muscles and in motor neurons in the brain. In the muscle, it binds neural agrin released from the nerve terminals initiating the signal via MuSK for AChR clustering (43). LRP4 antibodies belong mostly to the IgG1 subclass and in vitro they have been shown to be capable of complement-mediated cell lysis $(13,44)$. However, the 
contribution of complement activation in their pathogenicity is still unclear and the main in vivo mechanism at play is thought to be inhibition of interaction with MuSK, causing disruption of normal NMJ organization (13, 44-46).

The overall prevalence of LRP4 antibodies in MG patients appears to be around $2 \%$ [i.e., $~ 19 \%$ of SNMG patients (47)], although there was considerable variation among initial studies with reported rates of $2-45 \%$, possibly due to differences in the detection method used, the source of the antigen (animal or human) and the populations studied (44-46). A lower prevalence has been reported among Chinese MG patients accounting for $0.8-1.7 \%$ of total and $1-2.9 \%$ of SNMG patients $(48,49)$. Interestingly, LRP4 antibodies have also been reported in 10$23 \%$ of amyotrophic lateral sclerosis (ALS) patients $(50,51)$ and in $3.6 \%$ patients with other neurological diseases but not in healthy controls (47). Despite their frequent detection in ALS, their detection is a significant aid in MG diagnosis in parallel with the clinical presentation of the patients.

\section{Patients With Other Antibody Specificities}

In addition to the main MG antibody specificities discussed above, a number of other autoantibody targets, both extracellular and intracellular, have emerged in MG patients.

\section{Extracellular Antigens}

Activation of the LRP4/MuSK complex to drive AChR clustering is caused by neural agrin. Agrin antibodies have been detected in $2-15 \%$ of MG patients, though in most cases they were also positive for antibodies against AChR, MuSK, or LRP4 (52-55). Agrin antibodies have also been found in $14 \%$ of ALS patients (50). However, they have been shown to inhibit agrin-induced MuSK activation in vitro, and immunization with neural agrin caused MG symptoms in experimental animals, suggesting that these antibodies are involved in MG pathology $(54,56)$. Their detection can be valuable for disease management, as they have been shown to be associated with moderate to severe symptoms and moderate response to treatment (52).

In some $\mathrm{MG}$ patients antibodies against the voltage gated potassium channel $\alpha$-subunit Kv1.4 have been found, which in addition to the central nervous system is expressed in skeletal and heart muscles. A prevalence of $11-18 \%$ among MG patients has been reported, although the associated symptom severity appears to depend on the population studied. In a Caucasian patient cohort Kv1.4 antibodies were associated with LOMG patients and mild disease, often remaining purely ocular (57), while in Japanese patients they correlated with increased disease severity, myasthenic crises and the presence of thymoma (5860 ). Furthermore, since in the Japanese cohort myocarditis or abnormal ECG findings were present in as many as 27 and $60 \%$, respectively of Kv1.4 antibody positive patients, they could be an important marker of myocarditis or cardiac dysfunction among Japanese MG patients.

The activity of acetylcholine on AChRs is controlled by the enzyme AChE, which breaks down acetylcholine to choline and acetate thus terminating its action. AChE is located close to the postsynaptic membrane, where it is anchored on MuSK via molecules of ColQ (61). Antibodies against both AChE and
ColQ have been found in some MG patients. AChE antibodies have been reported in 5-50\% of MG patients, but they are not specific for MG since they are also found in many patients with other autoimmune diseases, while no correlation has been identified with clinical characteristics or symptoms (62-64). ColQ antibodies have so far been detected in about $3 \%$ of MG patients, including among SNMG, although again they do not appear to be MG specific and no evidence of pathogenicity has been found yet (65). Finally, antibodies against collagen XIII, a transmembrane collagen, have been detected in the serum of about $7 \%$ of MG patients with AChR antibodies and $16 \%$ of SNMG, but their presence did not correlate with symptom severity (66). Furthermore, they too are not specific for MG, since they are also found in patients with Grave's ophthalmopathy (67). Overall, the lack of MG-specificity of AChE, ColQ, and collagen XIII antibodies as well as the lack of association with clinical characteristics, which might have attributed a prognostic value, make the usefulness of these antibodies in MG diagnosis uncertain and further investigation is required.

\section{Intracellular Antigens}

The first autoantibodies, after AChR antibodies, to be identified in MG were the striational antibodies, named after the characteristic staining patterns produced in sarcomere sections by patients' sera. The term in fact collectively refers to several antibodies directed against different muscle proteins including titin, the ryanodine receptor (RyR), actin, myosin, tropomyosin, filamin, and others (68-71). Although the pathogenicity of these antibodies is unlikely, due to the intracellular localization of their target antigens, the diagnostic and prognostic value for titin and RyR antibodies has long been established.

Titin is the largest protein known to date, a filamentous molecule with a molecular weight of up to $4,200 \mathrm{kDa}(72)$. Interestingly, titin antibodies only bind to a $30 \mathrm{kDa}$ domain, called MGT30, located near the A/I band junction (73). Until recently, titin antibodies were only found in MG patients with AChR antibodies, being detected in $20-40 \%$ of them. These antibodies show a strong correlation with disease age of onset, since they are present in about $6 \%$ of EOMG but $50-80 \%$ of nonthymomatous LOMG patients (74-78), but in $50-95 \%$ of EOMG with thymoma and only few non-thymoma patients, so their presence provides a strong indication for thymoma $(69,75,78-$ 82). Additionally, they appear to be prognostic of more severe disease in all age groups $(78,80,81,83)$. More recently, lowtiter titin antibodies were detected in SNMG as well (84). These low titin antibody titers did not correlate with the presence of thymoma, in accordance with previous findings that thymoma is unlikely in MG patients without AChR antibodies (82).

RyR is a transmembrane protein forming a calcium channel in the sarcoplasmic reticulum, where it mediates $\mathrm{Ca}^{2+}$ release into the cytoplasm, facilitating muscle contraction in response to stimulation. Similarly to titin antibodies, RyR antibodies are found in few EOMG but in up to $40 \%$ of LOMG patients, while they are found in $75 \%$ of thymomatous MG patients and their presence is prognostic of more severe disease progression (81, 85-88). 
Rapsyn is a scaffolding protein, which in the muscle plays a role in AChR clustering by linking the intracellular domains of the receptors (89). Antibodies against rapsyn have been found in about $15 \%$ of MG patients, including among SNMG (90). However, rapsyn antibodies have also been found in various other autoimmune disorders decreasing their value as MG specific diagnostic markers, while no correlation with disease severity has been identified (91).

Cortactin is a cytoplasmic protein also involved in AChR clustering downstream of MuSK. Cortactin antibodies have been detected in about $9.5 \%$ of $\mathrm{AChR}$ antibody positive $\mathrm{MG}$ patients and $24 \%$ of SNMG patients, while they seem to be associated with mild disease (92-94). Nonetheless, their importance for MG diagnosis is still unclear, since they are also found in $\sim 12.5 \%$ of patients with other autoimmune diseases and $5 \%$ of healthy controls (93), as well as up to $26 \%$ of patients with polymyositis, dermatomyositis, and immunemediated necrotizing myopathy (95).

\section{Relevance in MG Diagnosis}

Although involvement in pathogenicity of most of the above antibodies against extracellular targets is often not clear yet, their detection can be valuable for MG diagnosis, especially in the case of otherwise seronegative patients. However, further validation or improvement of the detection assays is necessary, since in many cases they appear to lack good specificity for MG. The detection of antibodies against intracellular antigens, has proven invaluable as markers of disease severity, or identification of comorbidities, such as titin antibody detection for thymoma in EOMG. Furthermore, these antibodies, although unlikely to be pathogenic themselves, can play a significant role in diagnosis of SNMG patients, where the pathogenic autoantibodies may not be detectable by current assays, like anti-titin antibodies detected by RIPA in AChR-seronegative patients (84).

\section{METHODS FOR SEROLOGICAL DIAGNOSIS OF MG}

Serological tests for the detection of autoantibodies play a vital role in MG diagnosis. Being minimally invasive methods, they do not present a major barrier for testing and a single serum sample could potentially be tested by several assays if required, without the need for repeated hospital visits by patients. Although a final diagnosis may rely on additional tests, such as electrophysiological examination or assessment of response to AChE inhibitors, the high specificity of many MG antibody assays considerably facilitates diagnosis (Table 1).

Radioimmunoprecipitation assays (RIPA) are to this day the golden standard of serological MG tests, due to their high sensitivity and their ability to provide quantitative data allowing detailed patient monitoring. RIPAs are widely applied for the detection of AChR, MuSK, and, less frequently, other antigens. The AChR antibody assay is based on indirect labeling of solubilized AChR with ${ }^{125} \mathrm{I}-\alpha$-bungarotoxin, a highly specific AChR antagonist $(102,103)$. AChR can be obtained from human muscle from amputees or, currently more common, from AChRexpressing cell lines, such as $\mathrm{CN} 21$, which have been engineered to express both the fetal and adult types of the receptor, thus also detecting antibodies against the AChR $\gamma$ subunit (104). The wide use of the AChR RIPA owes to the $\sim 99 \%$ specificity of the assay and its high sensitivity, which amounts to about $85 \%$ among GMG patients and 50\% for OMG (105). In fact, many of the "seronegative" by AChR RIPA OMG patients have been found positive by other assays and/or for other antigens including: cell based assay (CBA) for AChR clusters [up to 50\% (96)], for LRP4 [up to $27 \%$ (47)], for MuSK [16\% (100)], or RIPA for titin antibodies [12\% (84)] with some double positives; yet a few false-positives have been also referred by these assays. It is unknown whether the remaining "seronegative" OMG patients are true seronegative or have yet undetectable antibodies to known or yet unknown antigens. The fact that those OMG patients with AChR antibodies have generally low antibody titers may suggest that some of the remaining "seronegative" have yet undetectable AChR antibodies. Assays for the detection of blocking antibodies, i.e., antibodies that bind to the receptor binding site, which may not be detected by the conventional RIPA, have been developed and are also commercially available. The added value from the use of these assays is limited since most patients will have non-blocking antibodies as well, while ACh binding competition appears to be less important for pathogenesis compared to complement activation. MuSK antibodies are commonly detected using directly ${ }^{125}$ I-labeled MuSK, with very high specificity for MG (106). The detection of AChR and MuSK antibodies in the same patient by RIPA is rare $(107,108)$. Recently, we developed a RIPA for the detection of titin antibodies with ${ }^{125}$ I-labeled MGT30 and used it to test a large cohort of samples from European MG patients, including 372 SNMG, which do not usually have detectable titin antibodies by current methods. We found that $13.4 \%$ of SNMG patients had titin antibodies, as well as 14.6 and $16.4 \%$ of patients with MuSK and LRP4 antibodies, respectively (84). The RIPA-detected titin antibodies in SNMG were not predictive of more severe disease. Nonetheless, titin antibodies detected by RIPA are a valuable biomarker for the diagnosis of otherwise SNMG patients.

Efforts to improve the sensitivity of the classical RIPA have resulted in the development of modified assays, using much larger serum volumes in order to detect antibodies at lower titers. Different approaches have been explored in order to minimize non-specific binding, which would render the use of large serum volumes impossible. In the case of AChR antibodies, semi-purified anti-human IgG was used as secondary antibody, allowing an increase of serum volumes by 16 -fold and consequently reducing the positivity titer cut-off value from 0.5 to $0.1 \mathrm{nM}$ (109). The application of this method allowed the detection of AChR antibodies in 20 of 81 previously SNMG patients tested. For MuSK antibody detection a two-step approach has been proposed, initially semi-purifying the MuSK antibodies by affinity chromatography with sepharose-immobilized MuSK and then using the concentrated antibodies for standard RIPA (110). This modification allowed the use of up to 50 times larger serum volumes for the assay, which resulted in the 
TABLE 1 | Autoantibody specificities in MG with clinical associations and common detection assays used.

\begin{tabular}{|c|c|c|c|c|}
\hline & $\begin{array}{l}\text { Target } \\
\text { antigen }\end{array}$ & Detection assay* & Clinical presentation & References \\
\hline \multirow[t]{9}{*}{ Extracellular } & AChR & $\begin{array}{l}\text { RIPA: Good specificity ( } \sim 99 \%) \text { and sensitivity } \\
\text { ( } \sim 85 \% \text { for GMG and } \sim 50 \% \text { for OMG). Requirement } \\
\text { for specialized equipment and use of radioactivity. }\end{array}$ & $\begin{array}{l}\text { The major MG subgroup. } \\
\text { Practically all MG symptoms may be present. } \\
\text { The presence of AChR antibodies is very rare in } \\
\text { other diseases. } \\
\text { Thymic abnormalities (mostly thymic hyperplasia) } \\
\text { are common, and thymoma in } \sim 10 \% \text { of patients. }\end{array}$ & $\begin{array}{l}\text { Several references, } \\
\text { including }(7,96-99)\end{array}$ \\
\hline & & $\begin{array}{l}\text { CBA (clustered AChR): Allows detection of } \\
\text { antibodies bound only to high density AChRs, or } \\
\text { those whose epitopes are altered during receptor } \\
\text { solubilization. Detection of } \sim 20 \% \text { of previously } \\
\text { SNMG. Requirement for specialized equipment. }\end{array}$ & & \\
\hline & & ELISA & & \\
\hline & & $\begin{array}{l}\text { CBA: Detection of } 8-13 \% \text { of patients negative for } \\
\text { AChR and MuSK antibodies by RIPA. Can detect up } \\
\text { to } \sim 99 \% \text { of RIPA-positive samples and has } \sim 100 \% \\
\text { specificity when lgG FC-specific 2nd antibodies are } \\
\text { used. }\end{array}$ & & \\
\hline & LRP4 & ELISA & $\begin{array}{l}\text { Milder symptoms than AChR antibody positive MG. } \\
\text { No thymoma. }\end{array}$ & $(47,50)$ \\
\hline & & $\begin{array}{l}\text { CBA: Detection in } ~ 6-19 \% \text { of SNMG patients, but } \\
\text { also in } 10-23 \% \text { of ALS patients. }\end{array}$ & & \\
\hline & Agrin & $\begin{array}{l}\text { ELISA or CBA: Detected in up to } 15 \% \text { of MG } \\
\text { patients, mostly seropositive. They have also been } \\
\text { found in } 14 \% \text { of ALS patients. }\end{array}$ & $\begin{array}{l}\text { Associated with more severe symptoms and } \\
\text { moderate response to treatment. }\end{array}$ & $(50,53)$ \\
\hline & $\mathrm{ColQ}$ & $\begin{array}{l}\text { CBA: Found in } \sim 3 \% \text { of MG patients, but lack } \\
\text { specificity. }\end{array}$ & Not determined. & (65) \\
\hline & $\begin{array}{l}\text { Collagen } \\
\text { XIII }\end{array}$ & $\begin{array}{l}\text { ELISA: Found in } \sim 16 \% \text { of SNMG. They are also } \\
\text { associated with Grave's ophthalmopathy. }\end{array}$ & No association with disease severity apparent. & $(66,67)$ \\
\hline \multirow[t]{5}{*}{ Intracellular } & Titin & $\begin{array}{l}\text { ELISA: Detection of titin antibodies only in AChR Ab } \\
\text { positive MG. }\end{array}$ & $\begin{array}{l}\text { More common in LOMG, rare in non-thymomatous } \\
\text { EOMG, but present in } 50-95 \% \text { of EOMG with } \\
\text { thymoma. Their presence corelates with increased } \\
\text { symptom severity }\end{array}$ & $(69,71,78,81,84)$ \\
\hline & & $\begin{array}{l}\text { RIPA: Detection of titin antibodies in all MG } \\
\text { subgroups, including } 13.4 \% \text { of SNMG (low titers). }\end{array}$ & $\begin{array}{l}\text { MG biomarker in "seronegative" MG. } \\
\text { Low titer antibodies detected by RIPA are not } \\
\text { prognostic of more severe disease or thymoma. }\end{array}$ & \\
\hline & RyR & $\begin{array}{l}\text { Immunoblots or ELISA: Detection of RyR antibodies } \\
\text { only in AChR Ab positive MG. }\end{array}$ & $\begin{array}{l}\text { Present in } 75 \% \text { of thymomatous MG patients. Their } \\
\text { presence corelates with increased symptom } \\
\text { severity. }\end{array}$ & $(85,88)$ \\
\hline & Rapsyn & $\begin{array}{l}\text { Immunoblots: Detected in } \sim 17 \% \text { of SNMG, but } \\
\text { they were also detected in } 10 \text { and } 78 \% \text { of OND and } \\
\text { SLE patients, respectively. }\end{array}$ & No association with disease severity apparent. & $(90)$ \\
\hline & Cortactin & $\begin{array}{l}\text { ELISA or Western blot: Detected in up to } 24 \% \text { of } \\
\text { SNMG, but not specific-also present in } 12.5 \% \text { of } \\
\text { other autoimmune diseases and up to } 26 \% \text { of } \\
\text { myositis patients. }\end{array}$ & $\begin{array}{l}\text { They have been reported to be prognostic of mild } \\
\text { disease. }\end{array}$ & $(92,93)$ \\
\hline
\end{tabular}

${ }^{*}$ Not all assay are available for routine diagnosis yet. 
detection of previously SNMG patients, without a compromise in specificity.

Enzyme-linked immunosorbent assays (ELISAs) have also been in use for the detection of AChR and MuSK antibodies, though less commonly than RIPA $(97,111)$. The ELISA has advantages as it does not involve the use of radioactivity and can be performed with standard equipment in most laboratories. For AChR antibodies, different ELISAs have been developed, either directly coating AChR onto ELISA plates followed by serum incubation, or by preincubation of AChR with serum in solution followed by measuring the inhibition of binding to a set of AChR monoclonal antibodies (immobilized and in solution). Although some studies have found the ELISA as specific and at least as sensitive as the RIPA, in others the ELISA presents with lower specificity and sensitivity, perhaps explaining its limited adoption (97, 98, 111). Assays aiming at the detection of modulating or blocking antibodies have also been developed, but they did not improve the sensitivity significantly compared to the standard RIPA $(112,113)$. On the other hand, ELISA with immobilized titin MGT30 domain is currently the most widely used method for the detection of titin antibodies. Other antibodies usually tested for by ELISA include cortactin and RyR antibodies using as antigen recombinant protein domains (114).

Several efforts have been made to produce other non-radioactive alternatives to RIPA with comparable sensitivity. A promising solution appears to be fluorescence immunoprecipitation assay (FIPA), which involves labeling of the target antigen with a fluorescent dye. In one approach for AChR labeling, the $\alpha, \gamma$, and $\varepsilon$ subunits were tagged with EGFP, before transfection together with the remaining subunits into HEK293 cells, while for MuSK the extracellular domain only was used labeled with maccherry and expressed in insect S2 cells (115). The overall sensitivity was shown to be very close to that of the RIPA for both AChR and MuSK antibodies. Furthermore, by labeling each antigen with a different fluorescent dye both AChR and MuSK antibodies could be detected simultaneously in the same assay, thus potentially reducing the cost and time for diagnosis. A similar method based on labeling recombinant fragments of the AChR $\alpha$ subunit with Renilla luciferase has been developed with good specificity (97\%), but it was able to detect AChR antibodies only in 32\% of MG patients, potentially due to the use of part of the $\alpha$ subunit rather than whole AChR (116). Further investigation with respect to the diagnostic value of assays employing AChR fragments is necessary.

The application of CBAs in MG diagnosis has been expanding over the last years. The method involves the transient or stable expression of the target antigen in a cell line, followed by incubation of the cells with test serum and the detection of autoantibody binding by fluorescence microscopy using labeled secondary or tertiary antibodies.

In the case of AChR antibody CBA, co-transfection of the cells with rapsyn, in addition to the AChR subunits, induced clustering of the receptors, thus permitting detection of antibodies that bind only to high density AChRs mimicking their clustering at the NMJ, or of antibodies whose epitopes are altered by the detergent solubilisation of membranes during the isolation of AChR antigen. Despite initial reports of high seropositivity found among SNMG with CBA for AChR antibodies (96, 99, $100,109,117,118)$, routine diagnosis suggests that the overall frequency of antibodies against clustered AChRs in SNMG patients is around $20 \%$ or less $(100,119)$. Autoantibody titration can be achieved by using serial dilutions of sera, but based on our experience with both assays, it cannot reach the accuracy of the RIPA. Nonetheless, CBA has become invaluable for the diagnosis of SNMG patients, with several studies reporting detection of $\mathrm{AChR}$ antibodies that were undetected by other current diagnostics $(115,118,120,121)$. On the other hand, even for sera found positive for AChR antibodies by RIPA, a CBA test could be useful to confirm that the detected antibodies bind on the cell embedded AChR. The use of both fetal and adult forms of the AChR not only appears to increase the sensitivity of the assay, but also enables the discrimination among fetal or adult AChR directed antibodies (122). The latter is important for the diagnosis of transient neonatal MG not associated with maternal MG, a condition arising from the presence in the mother of antibodies against only the fetal AChR, which may not cause MG symptoms in the mother but can be detrimental for the new-born $(20,123,124)$.

CBAs have also contributed significantly in the detection of MuSK and LRP4 antibodies in previously SNMG patients, including Asian populations where MuSK-MG is less common (99, 115, 120, 125). We have used CBAs for MuSK and LRP4 to test a cohort of sera from 13 European countries including over 630 samples from SNMG patients. We found that about $13 \%$ of SNMG samples were positive for MuSK antibodies, with a variation in the rates among countries, ranging from 5-22\% (100). The MuSK CBA has allowed the detection of antibodies in SN-OMG patients as well, which is not common with RIPA (100, 115). Of note, most of the MuSK antibodies detected belonged to the IgM rather than IgG class. Using the LRP4 CBA, 19\% of SNMG were found positive for LRP4 antibodies with an intercountry variability of $7-33 \%$ (47). The percentage of patients positive for more than one antibody specificities has increased by the use of CBAs. In more detail, 7.5\% of AChR antibody positive and $15-20 \%$ of MuSK antibody positive sera have also been found positive for LRP4 antibodies, while $0.5-12.5 \%$ AChR antibody positive patients were reported positive for MuSK antibodies as well $(47,48,52,100)$.

Although the presence of antibodies only detectable by CBA is associated with milder disease and better response to treatment (118), these antibodies have also been shown to be pathogenic. Indeed, antibodies against clustered AChRs belong to the complement-activating subclasses and cause complement depositions on the cell surface (96). Furthermore, MuSK IgG antibodies, but not IgM, detected by CBA were shown to inhibit agrin-induced $\mathrm{AChR}$ clustering on the surface of $\mathrm{C} 2 \mathrm{C} 12$ myotubes (101).

The specificity of the secondary antibodies and by extension the antibody classes detected by CBA appears to be important (119). For example, anti-human antibodies directed against the intact light and heavy IgG chains can also bind to IgM, and possibly other antibody classes as well. A study using such secondary antibodies for MuSK CBA resulted in a significant decrease in specificity (11 and 19\% positives among the healthy 
and disease controls, respectively), as well as in sensitivity (101). On the other hand, the use of a secondary antibody specific for the Fc part of the IgG heavy chain, which does not cross-react with other Ig classes, resulted in the detection of $99 \%$ of MuSK RIPA positive samples and $100 \%$ specificity, although this was accompanied by a decrease in the number of positives among SNMG (101). Since IgM may not be pathogenic, the importance of discrimination of the antibody classes for diagnosis remains to be fully assessed.

Recently, a modified CBA approach was developed based on the generation of stably-transfected HEK293 cell with the target antigen and, following incubation with the test sera, autoantibodies were measured by FACS analysis, providing more quantitative results. The assay has been used for the detection of antibodies against various antigens such as Kv1.4 and even the intracellular titin (126). In fact, the cytometric CBA showed improved sensitivity compared to the ELISA for titin. Furthermore, it could facilitate the diagnosis of Kv1.4 antibodies despite the somewhat lower sensitivity compared to the currently used method, which is relatively complicated and laborious, involving the immunoprecipitation of ${ }^{35} \mathrm{~S}$-labeled cell extracts from rabdomyosarcoma and leukemic cells followed by electrophoresis analysis. The presence of a $70 \mathrm{kDa} \mathrm{Kv1.4}$ protein band in the former but not the latter extracts is considered a positive finding (59).

A significant disadvantage of most of the aforementioned methods is the requirement of specialized equipment and expertise. Efforts are made for the development of fast, easy to perform and instrument-free assays. The use of such assays in decentralized small clinics and doctors' offices could reduce the time to diagnosis significantly, improving disease management. To this end, we have developed an assay based on the immobilization of antigen on a stick-type solid surface (immunostick) at high density. The immunostick can be immersed in succession into the undiluted test serum, secondary antibodies and substrate solution, similar to standard ELISA, but with much reduced incubation times, allowing completion in less than an hour. Furthermore, immobilization of various antigens in different zones of the immunostick could allow the simultaneous detection of more than one MG autoantibodies. Evaluation of this method for the detection of AChR antibodies, showed that it had very good specificity and sensitivity (99 and $91 \%$, respectively) (127). A similar approach based on a modified dot-blot method, using AChR preparations immobilized onto nitrocellulose membrane, achieved the same sensitivity as the ELISA (128).

\section{DEVELOPMENT OF THERAPIES BASED ON AUTOANTIGEN SPECIFICITY}

In addition to its value for MG diagnosis, the determination of autoantibody specificities is important for efficient management of the disease. For example, the differentiation among AChR and MuSK antibody positive patients has important implications for therapy, since the latter can present with adverse effects when treated with $\mathrm{AChE}$ inhibitors, a common first line AChR-MG treatment, thymectomy, or the use of complement inhibitors does not appear to be beneficial to them (129). On the contrary, MuSK antibody positive patients usually respond very well to rituximab or therapeutic plasma exchange (130-132). Of note, the detection of any autoantibody specificity could provide an indication for the use of neonatal $\mathrm{Fc}$ receptor ( $\mathrm{FcRn}$ ) inhibitors, which work by blocking $\operatorname{IgG}$ recycling via the $\mathrm{FcRn}$, thus reducing IgG half-life and which show potential for MG treatment in recent clinical trials (133).

Current common treatments for MG include $\mathrm{AChE}$ inhibitors, immunosuppressive drugs, thymectomy, intravenous immunoglobulin (IVIG) and plasmapheresis $(1,134)$. However, these approaches are to a large extent not specific and can thus be accompanied by various side effects. The problem is augmented given the long-term immunosuppression that may be required, increasing the risk of infections or neoplasia. Furthermore, a number of patients may remain unresponsive to current treatments (132). The development of antigen-specific therapies targeting only the pathogenic components of the immune system would, therefore, greatly benefit MG patients. Knowledge of the autoantibody repertoire of each patient is vital for such approaches to be implemented, further underlining the role of serological diagnostics.

One approach would be antigen-specific immunoadsorption, which is based on the selective removal of the autoantibodies from the patient's circulation. The procedure is a modification of plasmapheresis, whereby the isolated plasma, instead of being discarded, is passed through a matrix allowing the removal of the autoantibodies, before being returned to the patient (135) (Figure 2). Since no replacement fluids would be needed as in plasmapheresis, an additional advantage of the approach will be the reduction in risk of infection or allergic reactions. Efforts to develop such a matrix have been made by immobilization of recombinant extracellular domains of AChR or MuSK onto sepharose. Expression of the recombinant proteins has been optimized to achieve sufficient production yield and purity together with maximum antibody binding $(110,136)$. A number of in vitro experiments have established the efficiency, speed and specificity of AChR or MuSK autoantibody binding from sera of immunized experimental animals or MG patients $(28,137)$. Especially in the case of MuSK antibodies, immunoadsorption resulted in almost complete removal of the autoantibodies from all the patient sera tested. Furthermore, ex vivo immunoadsorption has been performed in rats with experimental autoimmune MG (EAMG), induced by immunization with human AChR or MuSK ECDs. The procedures resulted in quick and significant reduction of symptom severity, without the emergence of any adverse effects $(138,139)$. Although such an approach would not be a permanent cure as the autoantibodies would inevitably re-emerge, it would be greatly beneficial as a treatment option, providing immediate relief from symptoms when required, such as during myasthenic crises or pre-operatively.

Another approach for antigen-specific therapy would be to induce immunosuppression or immune tolerance in a targeted manner. In this case treatment would not have an immediate impact, but it would aim at a long-lasting or permanent 


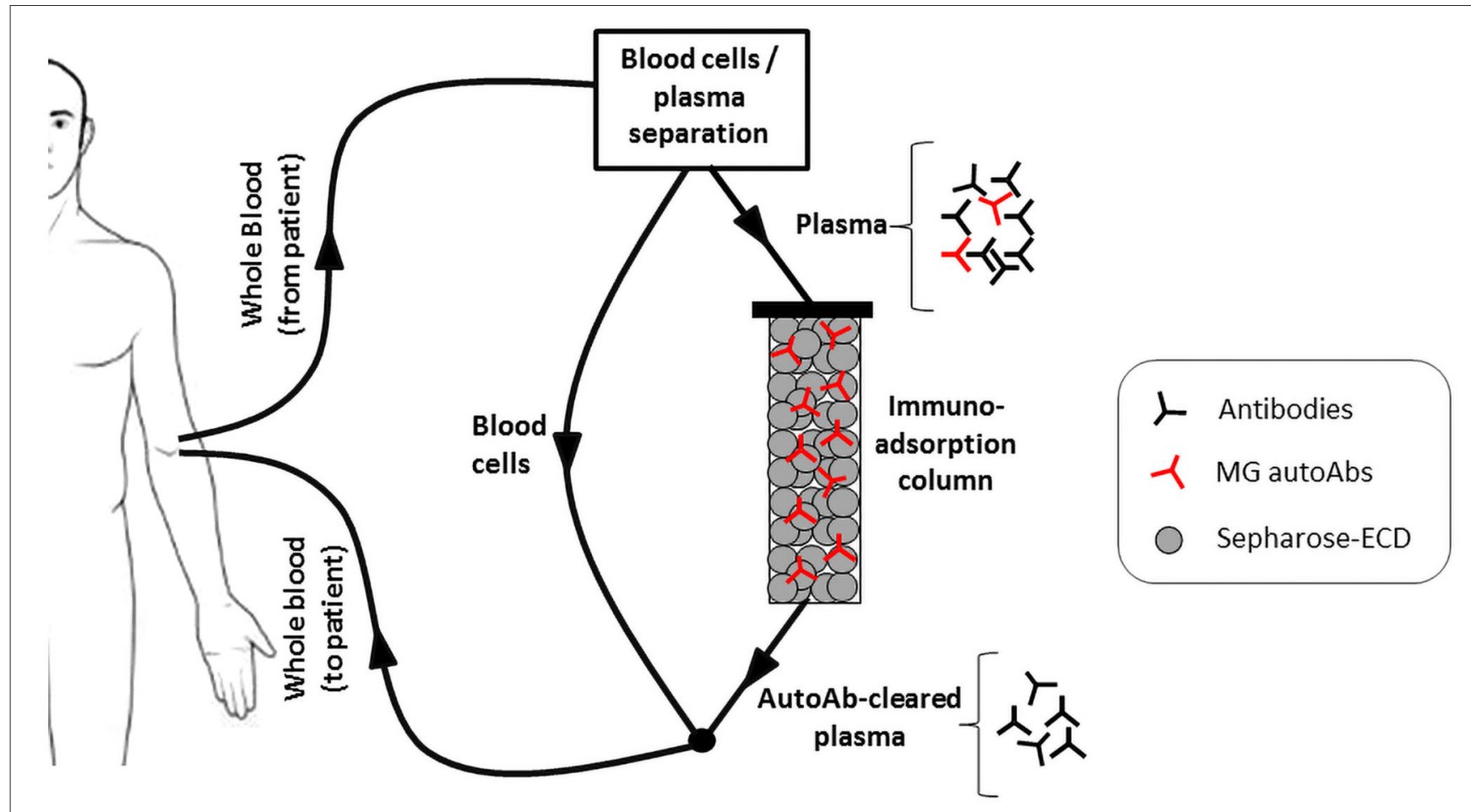

FIGURE 2 | The antigen specific immunoadsorption therapy approach. Recombinant extracellular domains (ECDs) of the AChR or MuSK are immobilized onto sepharose and packed into a column. During treatment, the patient's plasma is passed through it, allowing the selective binding and removal of only the MG autoantibodies. The autoantibody-depleted plasma is then returned to the patient.

effect. Indeed, studies have shown that EAMG symptoms can be prevented or ameliorated by oral or nasal administration of AChR or MuSK domains (140-144). In most studies the extracellular domain of the AChR $\alpha$ subunit has been used, while the response was not affected by the use of syngeneic (rat) or xenogeneic (human) AChR sequences (145). The therapeutic efficacy appeared to depend on the conformation of the administered antigens, with denatured proteins having a more pronounced effect (146). In fact an $\alpha$ subunit domain lacking some of the $\mathrm{B}$ cell epitopes has been found more efficient for treatment (147), suggesting that destruction of conformation-dependent $\mathrm{B}$ cell epitopes was responsible for the increased efficacy of denatured antigens. Furthermore, the use of AChR peptides corresponding to dominant $\mathrm{T}$ cell epitopes orally has been shown to ameliorate disease symptoms (148). Interestingly, a beneficial effect was also observed when dominant $\mathrm{T}$ cell epitopes were administered in the form of subcutaneous immunization in the presence of adjuvant (149). Conjugation of antigen derived peptides to immunomodulating protein domains as a means of targeting has also been explored to improve treatment potency with promising results (150). In most cases of tolerance induction, a shift in the $\mathrm{T}$ cell responses from Th1 to Th2 and/or Th3 was involved in mediating the therapeutic effect, evidenced by changes in the respective cytokine levels, mostly reduction in IFN-g, IL-2 and IL-12 and increase in IL10 and TGF- $\beta$ expression, accompanied by changes in the AChR IgG subclass distribution (144, 151-153).
The identification of peptides derived from the human AChR $\alpha$ subunit as $\mathrm{T}$ cell dominant epitopes, lead to the construction of altered peptides with single amino acid substitutions (termed altered peptide ligands, APL), some of which were found to inhibit T cell proliferative responses in vitro (154). Furthermore, oral administration of a dual APL (two APL peptides in tandem) in mice with EAMG, resulted in improvement of clinical manifestations and reduction of autoantibody titers (155). The therapeutic effect was marked by downregulation of the IFN$g$ and IL-2, upregulation of IL-10 and TGF- $\beta$, and induction of immunoregulatory CD4+CD25+ T cells $(156,157)$.

A different strategy relied on the administration of peptides incorporating only the intracellular domains of the AChR subunits, which have been shown to be incapable of disease induction (158). Although oral or nasal administration of the intracellular polypeptides was able to prevent and, in some cases, treat ongoing EAMG, the effect was greater when treatment was given as subcutaneous vaccination $(142,159)$. The mechanism of action appears to involve diverting the immunological response away from the production of ECD-targeting pathogenic antibodies, toward epitopes of the intracellular domains, and possibly causing apoptosis of AChR-specific plasma cells (160).

\section{CONCLUSION}

The clinical presentation of MG, its underlying pathophysiology and the response to treatment vary depending on the targeted 
autoantigens. Assays for the detection of MG autoantibodies are central in diagnosis, and they often serve as early diagnostics in cases of clinically suspected MG. Furthermore, since serological tests can identify the autoantibody specificities in MG patients, their role extends beyond disease diagnosis as invaluable tools for MG management. Patients with suspected MG but initially negative for autoantibodies, should be retested since usually the antibody titers increase and there is epitope spreading with disease progression. Nevertheless, some MG patients remain seronegative, making the discovery of novel antigenic targets or the development of more sensitive assays against known antigens invaluable. To this end, several new antigens recognized by autoantibodies in MG patients' sera have been identified over the last years, but the diagnostic relevance for most of them remains to be fully established.

RIPAs for AChR and MuSK antibodies have been the most widely used assays, owing to their very high sensitivity and specificity. The use of CBAs in routine diagnosis, mostly for clustered AChRs, MuSK and LRP4, is being slowly introduced during the recent years, contributing in reducing the number of SNMG patients. However, a significant disadvantage of CBAs currently is their limited capability of providing accurate titer information, which in addition to the lack of commercial kits, has resulted in their use mostly for patients negative by the standard RIPAs. Cytometric CBAs providing more quantitative results have already been proposed as a useful alternative, but their value for routine diagnosis remains to be assessed. Furthermore, simpler assays designed for quick instrument-free

\section{REFERENCES}

1. Gilhus NE, Skeie GO, Romi F, Lazaridis K, Zisimopoulou P, Tzartos S. Myasthenia gravis - autoantibody characteristics and their implications for therapy. Nat Rev Neurol. (2016) 12:259-68. doi: 10.1038/nrneurol.2016.44

2. Verschuuren JJ, Huijbers MG, Plomp JJ, Niks EH, Molenaar PC, MartinezMartinez $\mathrm{P}$, et al. Pathophysiology of myasthenia gravis with antibodies to the acetylcholine receptor, muscle-specific kinase and low-density lipoprotein receptor-related protein 4. Autoimmun Rev. (2013) 12:91823. doi: 10.1016/j.autrev.2013.03.001

3. Kummer TT, Misgeld T, Sanes JR. Assembly of the postsynaptic membrane at the neuromuscular junction: paradigm lost. Curr Opin Neurobiol. (2006) 16:74-82. doi: 10.1016/j.conb.2005.12.003

4. Sanes JR, Lichtman JW. Induction, assembly, maturation and maintenance of a postsynaptic apparatus. Nat Rev Neurosci. (2001) 2:791-805. doi: 10.1038/35097557

5. Lazaridis K, Tzartos SJ. Autoantibody specificities in myasthenia gravis; implications for improved diagnostics and therapeutics. Front Immunol. (2020) 11:212. doi: 10.3389/fimmu.2020.00212

6. Berrih-Aknin S, Le Panse R. Myasthenia gravis: a comprehensive review of immune dysregulation and etiological mechanisms. J Autoimmun. (2014) 52:90-100. doi: 10.1016/j.jaut.2013.12.011

7. Gilhus NE, Tzartos S, Evoli A, Palace J, Burns TM, Verschuuren J. Myasthenia gravis. Nat Rev Dis Primers. (2019) 5:30. doi: 10.1038/s41572-019-0079-y

8. Carr AS, Cardwell CR, McCarron PO, McConville J. A systematic review of population based epidemiological studies in Myasthenia Gravis. BMC Neurol. (2010) 10:46. doi: 10.1186/1471-2377-10-46

9. Lindstrom JM, Engel AG, Seybold ME, Lennon VA, Lambert EH. Pathological mechanisms in experimental autoimmune myasthenia gravis. II. Passive transfer of experimental autoimmune myasthenia gravis in rats sample analysis are being developed, which should decrease the time to diagnosis and contribute to the improvement of patients' care when they become commercially available. Finally, not surprisingly due to the nature of serological tests, irrespective of sensitivity, there is currently no single assay detecting all seropositive patients. Therefore, the potential need to ultimately use different assays for the diagnosis of these few patients must not be overlooked by the clinicians.

The identification of the antigen targeted in individual MG patients, presents the unique opportunity to develop personalized antigen-specific therapies that would selectively target the autoimmune components of the immune system. Among the approaches studied are specific removal of the autoantibodies, induction of tolerance and diversion of the immune response from the targeted autoantigen. Several studies have shown their therapeutic potential, but further pre-clinical trials are required before they can progress to clinical application. The development of such personalized approaches would increase the treatment efficacy and reduce side effects, thus significantly improving the patients' quality of life, and should be the focus of further efforts.

\section{AUTHOR CONTRIBUTIONS}

KL and ST researched the bibliography for the review, made substantial contributions to the content, and reviewed and edited the manuscript. KL wrote the first draft. All authors contributed to the article and approved the submitted version. with anti-acetylcholine receptor antibodies. J Exp Med. (1976) 144:73953. doi: $10.1084 /$ jem.144.3.739

10. Kordas G, Lagoumintzis G, Sideris S, Poulas K, Tzartos SJ. Direct proof of the in vivo pathogenic role of the AChR autoantibodies from myasthenia gravis patients. PLoS ONE. (2014) 9:e108327. doi: 10.1371/journal.pone.0108327

11. Newsom-Davis J, Wilson SG, Vincent A, Ward CD. Long-term effects of repeated plasma exchange in myasthenia gravis. Lancet. (1979) 1:4648. doi: 10.1016/S0140-6736(79)90823-7

12. Cole RN, Reddel SW, Gervasio OL, Phillips WD. Anti-MuSK patient antibodies disrupt the mouse neuromuscular junction. Ann Neurol. (2008) 63:782-9. doi: 10.1002/ana.21371

13. Shen C, Lu Y, Zhang B, Figueiredo D, Bean J, Jung J, et al. Antibodies against low-density lipoprotein receptor-related protein 4 induce myasthenia gravis. J Clin Invest. (2013) 123:5190-202. doi: 10.1172/JCI66039

14. Kalamida D, Poulas K, Avramopoulou V, Fostieri E, Lagoumintzis $\mathrm{G}$, Lazaridis $\mathrm{K}$, et al. Muscle and neuronal nicotinic acetylcholine receptors. Structure, function and pathogenicity. FEBS J. (2007) 274:3799845. doi: $10.1111 / j .1742-4658.2007 .05935 . x$

15. Tzartos SJ, Lindstrom JM. Monoclonal antibodies used to probe acetylcholine receptor structure: localization of the main immunogenic region and detection of similarities between subunits. Proc Natl Acad Sci USA. (1980) 77:755-9. doi: 10.1073/pnas.77.2.755

16. Tzartos SJ, Barkas T, Cung MT, Mamalaki A, Marraud M, Orlewski P, et al. Anatomy of the antigenic structure of a large membrane autoantigen, the muscle-type nicotinic acetylcholine receptor. Immunol Rev. (1998) 163:89120. doi: 10.1111/j.1600-065X.1998.tb01190.x

17. Luo J, Lindstrom J. Antigenic structure of the human muscle nicotinic acetylcholine receptor main immunogenic region. J Mol Neurosci. (2010) 40:217-20. doi: 10.1007/s12031-009-9271-y

18. Kostelidou K, Trakas N, Tzartos SJ. Extracellular domains of the beta, gamma and epsilon subunits of the human acetylcholine receptor as 
immunoadsorbents for myasthenic autoantibodies: a combination of immunoadsorbents results in increased efficiency. J Neuroimmunol. (2007) 190:44-52. doi: 10.1016/j.jneuroim.2007.07.018

19. Zisimopoulou P, Lagoumintzis G, Kostelidou K, Bitzopoulou K, Kordas G, Trakas N, et al. Towards antigen-specific apheresis of pathogenic autoantibodies as a further step in the treatment of myasthenia gravis by plasmapheresis. J Neuroimmunol. (2008) 201-2:95-103. doi: 10.1016/j.jneuroim.2008.06.020

20. Vincent A, Newland C, Brueton L, Beeson D, Riemersma S, Huson SM, et al. Arthrogryposis multiplex congenita with maternal autoantibodies specific for a fetal antigen. Lancet. (1995) 346:24-5. doi: 10.1016/S0140-6736(95)92652-6

21. Vrolix K, Fraussen J, Losen M, Stevens J, Lazaridis K, Molenaar PC, et al. Clonal heterogeneity of thymic B cells from early-onset myasthenia gravis patients with antibodies against the acetylcholine receptor. J Autoimmun. (2014) 52:101-12. doi: 10.1016/j.jaut.2013.12.008

22. Engel AG, Arahata $\mathrm{K}$. The membrane attack complex of complement at the endplate in myasthenia gravis. Ann N Y Acad Sci. (1987) 505:32632. doi: 10.1111/j.1749-6632.1987.tb51301.x

23. Rodgaard A, Nielsen FC, Djurup R, Somnier F, Gammeltoft S. Acetylcholine receptor antibody in myasthenia gravis: predominance of $\operatorname{IgG}$ subclasses 1 and 3. Clin Exp Immunol. (1987) 67:82-8.

24. Drachman DB, Angus CW, Adams RN, Michelson JD, Hoffman GJ. Myasthenic antibodies cross-link acetylcholine receptors to accelerate degradation. N Engl J Med. (1978) 298:111622. doi: 10.1056/NEJM197805182982004

25. Drachman DB, Adams RN, Josifek LF, Self SG. Functional activities of autoantibodies to acetylcholine receptors and the clinical severity of myasthenia gravis. $N$ Engl J Med. (1982) 307:769-75. doi: 10.1056/NEJM198209233071301

26. Oosterhuis HJ, Limburg PC, Hummel-Tappel E, The TH. Antiacetylcholine receptor antibodies in myasthenia gravis. Part 2. Clinical and serological follow-up of individual patients. J Neurol Sci. (1983) 58:371-85. doi: 10.1016/0022-510X(83)90096-5

27. Meriggioli MN, Sanders DB. Muscle autoantibodies in myasthenia gravis: beyond diagnosis? Expert Rev Clin Immunol. (2012) 8:42738. doi: 10.1586/eci.12.34

28. Skriapa L, Zisimopoulou P, Trakas N, Grapsa E, Tzartos SJ. Expression of extracellular domains of muscle specific kinase (MuSK) and use as immunoadsorbents for the development of an antigen-specific therapy. $J$ Neuroimmunol. (2014) 276:150-8. doi: 10.1016/j.jneuroim.2014.09.013

29. Hoch W, McConville J, Helms S, Newsom-Davis J, Melms A, Vincent A. Auto-antibodies to the receptor tyrosine kinase MuSK in patients with myasthenia gravis without acetylcholine receptor antibodies. Nat Med. (2001) 7:365-8. doi: 10.1038/85520

30. Koneczny I, Cossins J, Waters P, Beeson D, Vincent A. MuSK myasthenia gravis IgG4 disrupts the interaction of LRP4 with MuSK but both IgG4 and IgG1-3 can disperse preformed agrin-independent AChR clusters. PLoS ONE. (2013) 8:e80695. doi: 10.1371/journal.pone.0080695

31. Huijbers MG, Zhang W, Klooster R, Niks EH, Friese MB, Straasheijm KR, et al. MuSK IgG4 autoantibodies cause myasthenia gravis by inhibiting binding between MuSK and Lrp4. Proc Natl Acad Sci USA. (2013) 110:207838. doi: 10.1073/pnas.1313944110

32. Kawakami Y, Ito M, Hirayama M, Sahashi K, Ohkawara B, Masuda A, et al. Anti-MuSK autoantibodies block binding of collagen Q to MuSK. Neurology. (2011) 77:1819-26. doi: 10.1212/WNL.0b013e318237f660

33. Gomez AM, Van Den Broeck J, Vrolix K, Janssen SP, Lemmens MA, Van Der Esch E, et al. Antibody effector mechanisms in myasthenia gravispathogenesis at the neuromuscular junction. Autoimmunity. (2010) 43:35370. doi: 10.3109/08916930903555943

34. Koneczny I, Stevens JA, De Rosa A, Huda S, Huijbers MG, Saxena A, et al. IgG4 autoantibodies against muscle-specific kinase undergo Fabarm exchange in myasthenia gravis patients. J Autoimmun. (2017) 77:104115. doi: 10.1016/j.jaut.2016.11.005

35. Kostera-Pruszczyk A, Kaminska A, Dutkiewicz M, Emeryk-Szajewska B, Strugalska-Cynowska MH, Vincent A, et al. MuSK-positive myasthenia gravis is rare in the Polish population. Eur J Neurol. (2008) 15:7204. doi: $10.1111 / j .1468-1331.2008 .02176 . x$
36. Niks EH, Kuks JB, Verschuuren JJ. Epidemiology of myasthenia gravis with anti-muscle specific kinase antibodies in The Netherlands. J Neurol Neurosurg Psychiatry. (2007) 78:417-8. doi: 10.1136/jnnp.2006.102517

37. Sanders DB, El-Salem K, Massey JM, McConville J, Vincent A. Clinical aspects of MuSK antibody positive seronegative MG. Neurology. (2003) 60:1978-80. doi: 10.1212/01.WNL.0000065882.63904.53

38. Scuderi F, Marino M, Colonna L, Mannella F, Evoli A, Provenzano C, et al. Anti-p110 autoantibodies identify a subtype of "seronegative" myasthenia gravis with prominent oculobulbar involvement. Lab Invest. (2002) 82:113946. doi: 10.1097/01.LAB.0000028144.48023.9B

39. Tsiamalos P, Kordas G, Kokla A, Poulas K, Tzartos SJ. Epidemiological and immunological profile of muscle-specific kinase myasthenia gravis in Greece. Eur J Neurol. (2009) 16:925-30. doi: 10.1111/j.1468-1331.2009. 02624.x

40. Suzuki S, Utsugisawa K, Nagane Y, Satoh T, Kuwana M, Suzuki N. Clinical and immunological differences between early and lateonset myasthenia gravis in Japan. J Neuroimmunol. (2011) 230:14852. doi: 10.1016/j.jneuroim.2010.10.023

41. Niks EH, van Leeuwen Y, Leite MI, Dekker FW, Wintzen AR, Wirtz $\mathrm{PW}$, et al. Clinical fluctuations in MuSK myasthenia gravis are related to antigen-specific IgG4 instead of IgG1. J Neuroimmunol. (2008) 195:1516. doi: 10.1016/j.jneuroim.2008.01.013

42. Bartoccioni E, Scuderi F, Minicuci GM, Marino M, Ciaraffa F, Evoli A. AntiMuSK antibodies: correlation with myasthenia gravis severity. Neurology. (2006) 67:505-7. doi: 10.1212/01.wnl.0000228225.23349.5d

43. Kim N, Stiegler AL, Cameron TO, Hallock PT, Gomez AM, Huang JH, et al. Lrp4 is a receptor for Agrin and forms a complex with MuSK. Cell. (2008) 135:334-42. doi: 10.1016/j.cell.2008.10.002

44. Higuchi O, Hamuro J, Motomura M, Yamanashi Y. Autoantibodies to lowdensity lipoprotein receptor-related protein 4 in myasthenia gravis. Ann Neurol. (2011) 69:418-22. doi: 10.1002/ana.22312

45. Pevzner A, Schoser B, Peters K, Cosma NC, Karakatsani A, Schalke B, et al. Anti-LRP4 autoantibodies in AChR- and MuSK-antibody-negative myasthenia gravis. J Neurol. (2012) 259:427-35. doi: 10.1007/s00415-011-6194-7

46. Zhang B, Tzartos JS, Belimezi M, Ragheb S, Bealmear B, Lewis RA, et al. Autoantibodies to lipoprotein-related protein 4 in patients with double-seronegative myasthenia gravis. Arch Neurol. (2012) 69:44551. doi: 10.1001/archneurol.2011.2393

47. Zisimopoulou P, Evangelakou P, Tzartos J, Lazaridis K, Zouvelou V, Mantegazza R, et al. A comprehensive analysis of the epidemiology and clinical characteristics of anti-LRP4 in myasthenia gravis. J Autoimmun. (2014) 52:139-45. doi: 10.1016/j.jaut.2013.12.004

48. Li M, Han J, Zhang Y, Lv J, Zhang J, Zhao X, et al. Clinical analysis of Chinese anti-low-density-lipoprotein-receptor-associated protein 4 antibodies in patients with myasthenia gravis. Eur J Neurol. (2019) 26:1296e84. doi: 10.1111/ene.13979

49. Li Y, Zhang Y, Cai G, He D, Dai Q, Xu Z, et al. Anti-LRP4 autoantibodies in Chinese patients with myasthenia gravis. Muscle Nerve. (2017) 56:938942. doi: $10.1002 /$ mus. 25591

50. Rivner MH, Liu S, Quarles B, Fleenor B, Shen C, Pan J, et al. Agrin and low-density lipoprotein-related receptor protein 4 antibodies in amyotrophic lateral sclerosis patients. Muscle Nerve. (2017) 55:4302. doi: $10.1002 /$ mus. 25438

51. Tzartos JS, Zisimopoulou P, Rentzos M, Karandreas N, Zouvelou $\mathrm{V}$, Evangelakou P, et al. LRP4 antibodies in serum and CSF from amyotrophic lateral sclerosis patients. Ann Clin Transl Neurol. (2014) 1:807. doi: $10.1002 / \mathrm{acn} 3.26$

52. Cordts I, Bodart N, Hartmann K, Karagiorgou K, Tzartos JS, Mei L, et al. Screening for lipoprotein receptor-related protein 4-, agrin-, and titinantibodies and exploring the autoimmune spectrum in myasthenia gravis. J Neurol. (2017) 264:1193-203. doi: 10.1007/s00415-017-8514-Z

53. Cossins J, Belaya K, Zoltowska K, Koneczny I, Maxwell S, Jacobson L, et al. The search for new antigenic targets in myasthenia gravis. Ann N Y Acad Sci. (2012) 1275:123-8. doi: 10.1111/j.1749-6632.2012.06833.x

54. Zhang B, Shen C, Bealmear B, Ragheb S, Xiong WC, Lewis RA, et al. Autoantibodies to agrin in myasthenia gravis patients. PLoS ONE. (2014) 9:e91816. doi: 10.1371/journal.pone.0091816 
55. Gasperi C, Melms A, Schoser B, Zhang Y, Meltoranta J, Risson V, et al. Anti-agrin autoantibodies in myasthenia gravis. Neurology. (2014) 82:197683. doi: 10.1212/WNL.0000000000000478

56. Yan M, Liu Z, Fei E, Chen W, Lai X, Luo B, et al. Induction of antiagrin antibodies causes myasthenia gravis in mice. Neuroscience. (2018) 373:113-21. doi: 10.1016/j.neuroscience.2018.01.015

57. Romi F, Suzuki S, Suzuki N, Petzold A, Plant GT, Gilhus NE. Anti-voltagegated potassium channel Kv1.4 antibodies in myasthenia gravis. J Neurol. (2012) 259:1312-6. doi: 10.1007/s00415-011-6344-y

58. Suzuki S, Baba A, Kaida K, Utsugisawa K, Kita Y, Tsugawa J, et al. Cardiac involvements in myasthenia gravis associated with anti-Kv1.4 antibodies. Eur J Neurol. (2014) 21:223-30. doi: 10.1111/ene.12234

59. Suzuki S, Satoh T, Yasuoka H, Hamaguchi Y, Tanaka K, Kawakami Y, et al. Novel autoantibodies to a voltage-gated potassium channel Kv1.4 in a severe form of myasthenia gravis. J Neuroimmunol. (2005) 170:1419. doi: 10.1016/j.jneuroim.2005.08.017

60. Suzuki S, Utsugisawa K, Yoshikawa H, Motomura M, Matsubara $\mathrm{S}$, Yokoyama K, et al. Autoimmune targets of heart and skeletal muscles in myasthenia gravis. Arch Neurol. (2009) 66:1334-8. doi: 10.1001/archneurol.2009.229

61. Cartaud A, Strochlic L, Guerra M, Blanchard B, Lambergeon M, Krejci E, et al. MuSK is required for anchoring acetylcholinesterase at the neuromuscular junction. J Cell Biol. (2004) 165:50515. doi: $10.1083 /$ jcb. 200307164

62. Geen J, Howells RC, Ludgate M, Hullin DA, Hogg SI. The prevalence of anti-acetylcholinesterase antibodies in autoimmune disease. Autoimmunity. (2004) 37:579-85. doi: 10.1080/08916930400021360

63. Mappouras DG, Philippou G, Haralambous S, Tzartos SJ, Balafas A, Souvatzoglou A, et al. Antibodies to acetylcholinesterase cross-reacting with thyroglobulin in myasthenia gravis and Graves's disease. Clin Exp Immunol. (1995) 100:336-43. doi: 10.1111/j.1365-2249.1995.tb03674.x

64. Provenzano C, Marino M, Scuderi F, Evoli A, Bartoccioni E. Antiacetylcholinesterase antibodies associate with ocular myasthenia gravis. $J$ Neuroimmunol. (2010) 218:102-6. doi: 10.1016/j.jneuroim.2009.11.004

65. Zoltowska Katarzyna M, Belaya K, Leite M, Patrick W, Vincent A, Beeson D. Collagen Q-a potential target for autoantibodies in myasthenia gravis. $J$ Neurol Sci. (2015) 348:241-4. doi: 10.1016/j.jns.2014.12.015

66. Tu H, Pirskanen-Matell R, Heikkinen A, Oikarainen T, Risteli J, Pihlajaniemi T. Autoimmune antibodies to collagen XIII in myasthenia gravis patients. Muscle Nerve. (2018) 57:506-10. doi: 10.1002/mus.25969

67. De Bellis A, Sansone D, Coronella C, Conte M, Iorio S, Perrino $S$, et al. Serum antibodies to collagen XIII: a further good marker of active Graves' ophthalmopathy. Clin Endocrinol. (2005) 62:24-9. doi: 10.1111/j.1365-2265.2004.02167.x

68. Williams CL, Lennon VA. Thymic B lymphocyte clones from patients with myasthenia gravis secrete monoclonal striational autoantibodies reacting with myosin, alpha actinin, or actin. J Exp Med. (1986) 164:104359. doi: 10.1084/jem.164.4.1043

69. Aarli JA, Stefansson K, Marton LS, Wollmann RL. Patients with myasthenia gravis and thymoma have in their sera IgG autoantibodies against titin. Clin Exp Immunol. (1990) 82:284-8. doi: 10.1111/j.1365-2249.1990. tb05440.x

70. Yamamoto T, Sato T, Sugita H. Antifilamin, antivinculin, and antitropomyosin antibodies in myasthenia gravis. Neurology. (1987) 37:1329-33. doi: 10.1212/WNL.37.8.1329

71. Skeie GO, Aarli JA, Gilhus NE. Titin and ryanodine receptor antibodies in myasthenia gravis. Acta Neurol Scand Suppl. (2006) 183:19-23. doi: 10.1111/j.1600-0404.2006.00608.x

72. Bang ML, Centner T, Fornoff F, Geach AJ, Gotthardt M, McNabb M, et al. The complete gene sequence of titin, expression of an unusual approximately $700-\mathrm{kDa}$ titin isoform, and its interaction with obscurin identify a novel Z-line to I-band linking system. Circ Res. (2001) 89:106572. doi: 10.1161/hh2301.100981

73. Gautel M, Lakey A, Barlow DP, Holmes Z, Scales S, Leonard K, et al. Titin antibodies in myasthenia gravis: identification of a major immunogenic region of titin. Neurology. (1993) 43:1581-5. doi: 10.1212/WNL.43.8.1581

74. Aarli JA, Myasthenia gravis in the elderly: is it different? Ann N Y Acad Sci. (2008) 1132:238-43. doi: 10.1196/annals.1405.040
75. Buckley C, Newsom-Davis J, Willcox N, Vincent A. Do titin and cytokine antibodies in MG patients predict thymoma or thymoma recurrence? Neurology. (2001) 57:1579-82. doi: 10.1212/WNL.57.9.1579

76. Romi F, Skeie GO, Gilhus NE, Aarli JA. Striational antibodies in myasthenia gravis: reactivity and possible clinical significance. Arch Neurol. (2005) 62:442-6. doi: 10.1001/archneur.62.3.442

77. Szczudlik P, Szyluk B, Lipowska M, Ryniewicz B, Kubiszewska J, Dutkiewicz $\mathrm{M}$, et al. Antititin antibody in early- and late-onset myasthenia gravis. Acta Neurol Scand. (2014) 130:229-33. doi: 10.1111/ane.12271

78. Yamamoto AM, Gajdos P, Eymard B, Tranchant C, Warter JM, Gomez $\mathrm{L}$, et al. Anti-titin antibodies in myasthenia gravis: tight association with thymoma and heterogeneity of nonthymoma patients. Arch Neurol. (2001) 58:885-90. doi: 10.1001/archneur.58.6.885

79. Baggi F, Andreetta F, Antozzi C, Simoncini O, Confalonieri P, Labeit $\mathrm{S}$, et al. Anti-titin and antiryanodine receptor antibodies in myasthenia gravis patients with thymoma. Ann N Y Acad Sci. (1998) 841:53841. doi: 10.1111/j.1749-6632.1998.tb10978.x

80. Chen XJ, Qiao J, Xiao BG, Lu CZ. The significance of titin antibodies in myasthenia gravis-correlation with thymoma and severity of myasthenia gravis. J Neurol. (2004) 251:1006-11. doi: 10.1007/s00415-004-0479-z

81. Romi F, Skeie GO, Aarli JA, Gilhus NE. Muscle autoantibodies in subgroups of myasthenia gravis patients. J Neurol. (2000) 247:36975. doi: 10.1007/s004150050604

82. Choi Decroos E, Hobson-Webb LD, Juel VC, Massey JM, Sanders DB. Do acetylcholine receptor and striated muscle antibodies predict the presence of thymoma in patients with myasthenia gravis? Muscle Nerve. (2014) 49:304. doi: 10.1002/mus. 23882

83. Somnier FE, Engel PJ. The occurrence of anti-titin antibodies and thymomas: a population survey of MG 1970-1999. Neurology. (2002) 59:928. doi: 10.1212/WNL.59.1.92

84. Stergiou C, Lazaridis K, Zouvelou V, Tzartos J, Mantegazza R, Antozzi C, et al. Titin antibodies in "seronegative" myasthenia gravis-a new role for an old antigen. J Neuroimmunol. (2016) 292:108-15. doi: 10.1016/j.jneuroim.2016.01.018

85. Takamori M, Motomura M, Kawaguchi N, Nemoto Y, Hattori T, Yoshikawa $\mathrm{H}$, et al. Anti-ryanodine receptor antibodies and FK506 in myasthenia gravis. Neurology. (2004) 62:1894-6. doi: 10.1212/01.WNL.0000125254. 99397.68

86. Mygland A, Tysnes OB, Matre R, Volpe P, Aarli JA, Gilhus NE. Ryanodine receptor autoantibodies in myasthenia gravis patients with a thymoma. Ann Neurol. (1992) 32:589-91. doi: 10.1002/ana.410320419

87. Romi F, Aarli JA, Gilhus NE. Myasthenia gravis patients with ryanodine receptor antibodies have distinctive clinical features. Eur J Neurol. (2007) 14:617-20. doi: 10.1111/j.1468-1331.2007.01785.x

88. Skeie GO, Lunde PK, Sejersted OM, Mygland A, Aarli JA, Gilhus NE. Myasthenia gravis sera containing antiryanodine receptor antibodies inhibit binding of $[3 \mathrm{H}]$-ryanodine to sarcoplasmic reticulum. Muscle Nerve. (1998) 21:329-35. doi: 10.1002/(SICI)1097-4598(199803)21:3<329::AID-MUS6>3. $0 . \mathrm{CO} ; 2-\mathrm{C}$.

89. Gautam M, Noakes PG, Mudd J, Nichol M, Chu GC, Sanes JR, et al. Failure of postsynaptic specialization to develop at neuromuscular junctions of rapsyn-deficient mice. Nature. (1995) 377:232-6. doi: 10.1038/377232a0

90. Agius MA, Zhu S, Kirvan CA, Schafer AL, Lin MY, Fairclough RH, et al. Rapsyn antibodies in myasthenia gravis. Ann N Y Acad Sci. (1998) 841:51621. doi: 10.1111/j.1749-6632.1998.tb10972.x

91. Agius MA, Zhu S, Aarli JA. Antirapsyn antibodies occur commonly in patients with lupus. Ann N Y Acad Sci. (1998) 841:525-6. doi: 10.1111/j.1749-6632.1998.tb10974.x

92. Cortes-Vicente E, Gallardo E, Martinez MA, Diaz-Manera J, Querol L, Rojas-Garcia R, et al. Clinical characteristics of patients with doubleseronegative myasthenia gravis and antibodies to cortactin. JAMA Neurol. (2016) 73:1099-104. doi: 10.1001/jamaneurol.2016.2032

93. Gallardo E, Martinez-Hernandez E, Titulaer MJ, Huijbers MG, Martinez MA, Ramos A, et al. Cortactin autoantibodies in myasthenia gravis. Autoimmun Rev. (2014) 13:1003-7. doi: 10.1016/j.autrev.2014.08.039

94. Illa I, Cortes-Vicente E, Martinez MA, Gallardo E. Diagnostic utility of cortactin antibodies in myasthenia gravis. Ann N Y Acad Sci. (2018) 1412:9094. doi: $10.1111 /$ nyas. 13502 
95. Labrador-Horrillo M, Martinez MA, Selva-O'Callaghan A, Trallero-Araguas E, Grau-Junyent JM, Vilardell-Tarres M, et al. Identification of a novel myositis-associated antibody directed against cortactin. Autoimmun Rev. (2014) 13:1008-12. doi: 10.1016/j.autrev.2014.08.038

96. Jacob S, Viegas S, Leite MI, Webster R, Cossins J, Kennett R, et al. Presence and pathogenic relevance of antibodies to clustered acetylcholine receptor in ocular and generalized myasthenia gravis. Arch Neurol. (2012) 69:9941001. doi: 10.1001/archneurol.2012.437

97. Hewer R, Matthews I, Chen S, McGrath V, Evans M, Roberts E, et al. A sensitive non-isotopic assay for acetylcholine receptor autoantibodies. Clin Chim Acta. (2006) 364:159-66. doi: 10.1016/j.cccn.2005.05.035

98. Martino G, Twaddle G, Brambilla E, Grimaldi LM. Detection of antiacetylcholine receptor antibody by an ELISA using human receptor from a rhabdomyosarcoma cell line. Acta Neurol Scand. (1994) 89:1822. doi: 10.1111/j.1600-0404.1994.tb01626.x

99. Leite MI, Jacob S, Viegas S, Cossins J, Clover L, Morgan BP, et al. IgG1 antibodies to acetylcholine receptors in 'seronegative' myasthenia gravis. Brain. (2008) 131:1940-52. doi: 10.1093/brain/awn092

100. Tsonis AI, Zisimopoulou P, Lazaridis K, Tzartos J, Matsigkou E, Zouvelou $\mathrm{V}$, et al. MuSK autoantibodies in myasthenia gravis detected by cell based assay-a multinational study. J Neuroimmunol. (2015) 284:107. doi: 10.1016/j.jneuroim.2015.04.015

101. Huda S, Waters P, Woodhall M, Leite MI, Jacobson L, De Rosa A, et al. IgG-specific cell-based assay detects potentially pathogenic MuSKAbs in seronegative MG. Neurol Neuroimmunol Neuroinflamm. (2017) 4:e357. doi: 10.1212/NXI.0000000000000357

102. Lindstrom J. An assay for antibodies to human acetylcholine receptor in serum from patients with myasthenia gravis. Clin Immunol Immunopathol. (1977) 7:36-43. doi: 10.1016/0090-1229(77)90027-7

103. Patrick J, Lindstrom J, Culp B, McMillan J. Studies on purified eel acetylcholine receptor and anti-acetylcholine receptor antibody. Proc Natl Acad Sci USA. (1973) 70:3334-8. doi: 10.1073/pnas.70.12.3334

104. Beeson D, Jacobson L, Newsom-Davis J, Vincent A. A transfected human muscle cell line expressing the adult subtype of the human muscle acetylcholine receptor for diagnostic assays in myasthenia gravis. Neurology. (1996) 47:1552-5. doi: 10.1212/WNL.47.6.1552

105. Benatar M. A systematic review of diagnostic studies in myasthenia gravis. Neuromuscul Disord. (2006) 16:459-67. doi: 10.1016/j.nmd.2006.05.006

106. Matthews I, Chen S, Hewer R, McGrath V, Furmaniak J, Rees Smith B. Muscle-specific receptor tyrosine kinase autoantibodiesa new immunoprecipitation assay. Clin Chim Acta. (2004) 348:95-9. doi: 10.1016/j.cccn.2004.05.008

107. Ohta K, Shigemoto K, Kubo S, Maruyama N, Abe Y, Ueda N, et al. MuSK antibodies in AChR Ab-seropositive MG vs AChR Ab-seronegative MG. Neurology. (2004) 62:2132-3. doi: 10.1212/01.WNL.0000129274.12702.92

108. Zouvelou V, Papathanasiou A, Koros C, Rentzos M, Zambelis T, Stamboulis E. Pure ocular anti-musk myasthenia under no immunosuppressive treatment. Muscle Nerve. (2013) 48:464. doi: 10.1002/mus.23847

109. Hong Y, Zisimopoulou P, Trakas N, Karagiorgou K, Stergiou C, Skeie GO, et al. Multiple antibody detection in 'seronegative' myasthenia gravis patients. Eur J Neurol. (2017) 24:844-50. doi: 10.1111/ene.13300

110. Trakas N, Zisimopoulou P, Tzartos SJ. Development of a highly sensitive diagnostic assay for muscle-specific tyrosine kinase (MuSK) autoantibodies in myasthenia gravis. J Neuroimmunol. (2011) 240-1:7986. doi: 10.1016/j.jneuroim.2011.09.007

111. Oger J, Frykman H. An update on laboratory diagnosis in myasthenia gravis. Clin Chim Acta. (2015) 449:43-8. doi: 10.1016/j.cca.2015.07.030

112. Chan $\mathrm{KH}$, Lachance $\mathrm{DH}$, Harper CM, Lennon VA. Frequency of seronegativity in adult-acquired generalized myasthenia gravis. Muscle Nerve. (2007) 36:651-8. doi: 10.1002/mus.20854

113. Howard FM, Jr., Lennon VA, Finley J, Matsumoto J, Elveback LR. Clinical correlations of antibodies that bind, block, or modulate human acetylcholine receptors in myasthenia gravis. Ann N Y Acad Sci. (1987) 505:52638. doi: 10.1111/j.1749-6632.1987.tb51321.x

114. Skeie GO, Mygland A, Treves S, Gilhus NE, Aarli JA, Zorzato F. Ryanodine receptor antibodies in myasthenia gravis: epitope mapping and effect on calcium release in vitro. Muscle Nerve. (2003) 27:819. doi: 10.1002/mus.10294
115. Yang L, Maxwell S, Leite MI, Waters P, Clover L, Fan X, et al. Non-radioactive serological diagnosis of myasthenia gravis and clinical features of patients from Tianjin, China. J Neurol Sci. (2011) 301:716. doi: 10.1016/j.jns.2010.10.023

116. Ching KH, Burbelo PD, Kimball RM, Clawson LL, Corse AM, Iadarola MJ. Recombinant expression of the AChR-alphal subunit for the detection of conformation-dependent epitopes in Myasthenia Gravis. Neuromuscul Disord. (2011) 21:204-13. doi: 10.1016/j.nmd.2010.12.003

117. Devic P, Petiot P, Simonet T, Stojkovic T, Delmont E, Franques J, et al. Antibodies to clustered acetylcholine receptor: expanding the phenotype. Eur J Neurol. (2014) 21:130-4. doi: 10.1111/ene.12270

118. Rodriguez Cruz PM, Al-Hajjar M, Huda S, Jacobson L, Woodhall M, Jayawant S, et al. Clinical features and diagnostic usefulness of antibodies to clustered acetylcholine receptors in the diagnosis of seronegative myasthenia gravis. JAMA Neurol. (2015) 72:642-9. doi: 10.1001/jamaneurol.2015.0203

119. Vincent A, Huda S, Cao M, Cetin H, Koneczny I, Rodriguez Cruz PM, et al. Serological and experimental studies in different forms of myasthenia gravis. Ann N Y Acad Sci. (2018) 1413:143-53. doi: 10.1111/nyas.13592

120. Chang T, Leite MI, Senanayake S, Gunaratne PS, Gamage R, Riffsy MT, et al. Clinical and serological study of myasthenia gravis using both radioimmunoprecipitation and cell-based assays in a South Asian population. J Neurol Sci. (2014) 343:82-7. doi: 10.1016/j.jns.2014.05.037

121. Yan C, Li W, Song J, Feng X, Xi J, Lu J, et al. Cell-based versus enzymelinked immunosorbent assay for the detection of acetylcholine receptor antibodies in Chinese juvenile myasthenia gravis. Pediatr Neurol. (2019) 98:74-9. doi: 10.1016/j.pediatrneurol.2019.01.016

122. Shi QG, Wang ZH, Ma XW, Zhang DQ, Yang CS, Shi FD, et al Clinical significance of detection of antibodies to fetal and adult acetylcholine receptors in myasthenia gravis. Neurosci Bull. (2012) 28:46974. doi: 10.1007/s12264-012-1256-0

123. Riemersma S, Vincent A, Beeson D, Newland C, Hawke S, Vernet-der Garabedian B, et al. Association of arthrogryposis multiplex congenita with maternal antibodies inhibiting fetal acetylcholine receptor function. J Clin Invest. (1996) 98:2358-63. doi: 10.1172/JCI119048

124. Saxena A, Stevens J, Cetin H, Koneczny I, Webster R, Lazaridis $\mathrm{K}$, et al. Characterization of an anti-fetal AChR monoclonal antibody isolated from a myasthenia gravis patient. Sci Rep. (2017) 7:14426. doi: 10.1038/s41598-017-14350-8

125. Han J, Zhang J, Li M, Zhang Y, Lv J, Zhao X, et al. A novel MuSK cell-based myasthenia gravis diagnostic assay. J Neuroimmunol. (2019) 337:577076. doi: 10.1016/j.jneuroim.2019.577076

126. Kufukihara K, Watanabe Y, Inagaki T, Takamatsu K, Nakane S, Nakahara $\mathrm{J}$, et al. Cytometric cell-based assays for anti-striational antibodies in myasthenia gravis with myositis and/or myocarditis. Sci Rep. (2019) 9:5284. doi: 10.1038/s41598-019-41730-Z

127. Trakas N, Tzartos SJ. Immunostick ELISA for rapid and easy diagnosis of myasthenia gravis. J Immunol Methods. (2018) 460:107-12. doi: 10.1016/j.jim.2018.06.016

128. Bokoliya S, Patil S, Nagappa M, Taly A. A simple, rapid and non-radiolabeled immune assay to detect anti-achr antibodies in myasthenia gravis. Lab Med. (2019) 50:229-235. doi: 10.1093/labmed/lmy038

129. Evoli A, Bianchi MR, Riso R, Minicuci GM, Batocchi AP, Servidei S, et al. Response to therapy in myasthenia gravis with anti-MuSK antibodies. Ann N Y Acad Sci. (2008) 1132:76-83. doi: 10.1196/annals.1405.012

130. Guptill JT, Sanders DB, Evoli A. Anti-MuSK antibody myasthenia gravis: clinical findings and response to treatment in two large cohorts. Muscle Nerve. (2011) 44:36-40. doi: 10.1002/mus.22006

131. Iorio R, Damato V, Alboini PE, Evoli A. Efficacy and safety of rituximab for myasthenia gravis: a systematic review and meta-analysis. J Neurol. (2015) 262:1115-9. doi: 10.1007/s00415-014-7532-3

132. Silvestri NJ, Wolfe GI. Treatment-refractory myasthenia gravis. J Clin Neuromuscul Dis. (2014) 15:167-78. doi: 10.1097/CND.0000000000000034

133. Gable KL, Guptill JT. Antagonism of the neonatal Fc receptor as an emerging treatment for myasthenia gravis. Front Immunol. (2019) 10:3052. doi: 10.3389/fimmu.2019.03052

134. Barnett C, Tabasinejad R, Bril V. Current pharmacotherapeutic options for myasthenia gravis. Expert Opin Pharmacother. (2019) 20:2295303. doi: 10.1080/14656566.2019.1682548 
135. Lazaridis K, Zisimopoulou P, Lagoumintzis G, Skriapa L, Trakas N, Evangelakou P, et al. Antigen-specific apheresis of autoantibodies in myasthenia gravis. Ann N Y Acad Sci. (2012) 1275:7-12. doi: 10.1111/j.1749-6632.2012.06788.x

136. Lazaridis K, Zisimopoulou P, Giastas P, Bitzopoulou K, Evangelakou P, Sideri A, et al. Expression of human AChR extracellular domain mutants with improved characteristics. Int J Biol Macromol. (2014) 63:2107. doi: 10.1016/j.ijbiomac.2013.11.003

137. Lazaridis K, Evaggelakou P, Bentenidi E, Sideri A, Grapsa E, Tzartos SJ. Specific adsorbents for myasthenia gravis autoantibodies using mutants of the muscle nicotinic acetylcholine receptor extracellular domains. $J$ Neuroimmunol. (2015) 278:19-25. doi: 10.1016/j.jneuroim.2014.12.001

138. Lazaridis K, Baltatzidou V, Tektonidis N, Tzartos SJ. Antigen-specific immunoadsorption of MuSK autoantibodies as a treatment of MuSKinduced experimental autoimmune myasthenia gravis. J Neuroimmunol. (2020) 339:577136. doi: 10.1016/j.jneuroim.2019.577136

139. Lazaridis K, Dalianoudis I, Baltatzidi V, Tzartos SJ. Specific removal of autoantibodies by extracorporeal immunoadsorption ameliorates experimental autoimmune myasthenia gravis. J Neuroimmunol. (2017) 312:24-30. doi: 10.1016/j.jneuroim.2017.09.001

140. Barchan D, Souroujon MC, Im SH, Antozzi C, Fuchs S. Antigen-specific modulation of experimental myasthenia gravis: nasal tolerization with recombinant fragments of the human acetylcholine receptor alpha-subunit. Proc Natl Acad Sci USA. (1999) 96:8086-91. doi: 10.1073/pnas.96.14.8086

141. Drachman DB, Okumura S, Adams RN, McIntosh KR. Oral tolerance in myasthenia gravis. Ann $N$ Y Acad Sci. (1996) 778:258-72. doi: 10.1111/j.1749-6632.1996.tb21134.x

142. Luo J, Lindstrom J. AChR-specific immunosuppressive therapy of myasthenia gravis. Biochem Pharmacol. (2015) 97:60919. doi: 10.1016/j.bcp.2015.07.011

143. Ma CG, Zhang GX, Xiao BG, Link J, Olsson T, Link $H$. Suppression of experimental autoimmune myasthenia gravis by nasal administration of acetylcholine receptor. J Neuroimmunol. (1995) 58:51-60. doi: 10.1016/0165-5728(94)00187-S

144. Reuveni D, Aricha R, Souroujon MC, Fuchs S. MuSK EAMG: immunological characterization and suppression by induction of oral tolerance. Front Immunol. (2020) 11:403. doi: 10.3389/fimmu.2020.00403

145. Maiti PK, Feferman T, Im SH, Souroujon MC, Fuchs S. Immunosuppression of rat myasthenia gravis by oral administration of a syngeneic acetylcholine receptor fragment. J Neuroimmunol. (2004) 152:112-20. doi: 10.1016/j.jneuroim.2004.04.010

146. Im SH, Barchan D, Souroujon MC, Fuchs S. Role of tolerogen conformation in induction of oral tolerance in experimental autoimmune myasthenia gravis. J Immunol. (2000) 165:3599-605. doi: 10.4049/jimmunol.165.7.3599

147. Yi HJ, Chae CS, So JS, Tzartos SJ, Souroujon MC, Fuchs S, et al. Suppression of experimental myasthenia gravis by a B-cell epitopefree recombinant acetylcholine receptor. Mol Immunol. (2008) 46:192201. doi: 10.1016/j.molimm.2008.08.264

148. Baggi F, Andreetta F, Caspani E, Milani M, Longhi R, Mantegazza R, et al. Oral administration of an immunodominant T-cell epitope downregulates Th1/Th2 cytokines and prevents experimental myasthenia gravis. J Clin Invest. (1999) 104:1287-95. doi: 10.1172/JCI7121

149. Wu B, Deng C, Goluszko E, Christadoss P. Tolerance to a dominant T cell epitope in the acetylcholine receptor molecule induces epitope spread and suppresses murine myasthenia gravis. J Immunol. (1997) 159:3016-23.
150. Consonni A, Sharma S, Schon K, Lebrero-Fernandez C, Rinaldi E, Lycke NY, et al. A novel approach to reinstating tolerance in experimental autoimmune myasthenia gravis using a targeted fusion protein, mCTA1-T146. Front Immunol. (2017) 8:1133. doi: 10.3389/fimmu.2017.01133

151. Im SH, Barchan D, Fuchs S, Souroujon MC. Suppression of ongoing experimental myasthenia by oral treatment with an acetylcholine receptor recombinant fragment. J Clin Invest. (1999) 104:1723-30. doi: 10.1172/JCI8121

152. Im SH, Barchan D, Fuchs S, Souroujon MC. Mechanism of nasal tolerance induced by a recombinant fragment of acetylcholine receptor for treatment of experimental myasthenia gravis. J Neuroimmunol. (2000) 111:1618. doi: $10.1016 / \mathrm{S} 0165-5728(00) 00395-7$

153. Okumura S, McIntosh K, Drachman DB. Oral administration of acetylcholine receptor: effects on experimental myasthenia gravis. Ann Neurol. (1994) 36:704-13. doi: 10.1002/ana.410360504

154. Katz-Levy Y, Kirshner SL, Sela M, Mozes E. Inhibition of T-cell reactivity to myasthenogenic epitopes of the human acetylcholine receptor by synthetic analogs. Proc Natl Acad Sci USA. (1993) 90:7000-4. doi: 10.1073/pnas.90.15.7000

155. Paas-Rozner M, Dayan M, Paas Y, Changeux JP, Wirguin I, Sela M, et al. Oral administration of a dual analog of two myasthenogenic $\mathrm{T}$ cell epitopes down-regulates experimental autoimmune myasthenia gravis in mice. Proc Natl Acad Sci USA. (2000) 97:2168-73. doi: 10.1073/pnas.040554597

156. Paas-Rozner M, Sela M, Mozes E. The nature of the active suppression of responses associated with experimental autoimmune myasthenia gravis by a dual altered peptide ligand administered by different routes. Proc Natl Acad Sci USA. (2001) 98:12642-7. doi: 10.1073/pnas.221456798

157. Aruna BV, Sela M, Mozes E. Down-regulation of T cell responses to AChR and reversal of EAMG manifestations in mice by a dual altered peptide ligand via induction of CD4(+)CD25(+) regulatory cells. J Neuroimmunol. (2006) 177:63-75. doi: 10.1016/j.jneuroim.2006.04.018

158. Luo J, Lindstrom J. Antigen-specific immunotherapeutic vaccine for experimental autoimmune myasthenia gravis. J Immunol. (2014) 193:504455. doi: 10.4049/jimmunol.1401392

159. Lindstrom J, Luo J, Kuryatov A. Myasthenia gravis and the tops and bottoms of AChRs: antigenic structure of the MIR and specific immunosuppression of EAMG using AChR cytoplasmic domains. Ann N Y Acad Sci. (2008) 1132:29-41. doi: 10.1196/annals.1405.007

160. Luo J, Lindstrom J. Acetylcholine receptor-specific immunosuppressive therapy of experimental autoimmune myasthenia gravis and myasthenia gravis. Ann N Y Acad Sci. (2018) 1413:76-81. doi: 10.1111/nyas.13550

Conflict of Interest: ST has shares in the research and diagnostic laboratory Tzartos NeuroDiagnostics.

The remaining author declares that the research was conducted in the absence of any commercial or financial relationships that could be construed as a potential conflict of interest.

Copyright ( $\odot 2020$ Lazaridis and Tzartos. This is an open-access article distributed under the terms of the Creative Commons Attribution License (CC BY). The use, distribution or reproduction in other forums is permitted, provided the original author(s) and the copyright owner(s) are credited and that the original publication in this journal is cited, in accordance with accepted academic practice. No use, distribution or reproduction is permitted which does not comply with these terms. 